\title{
Arable weeds as a case study in plant-human relationships beyond domestication
}

\author{
Amy Bogaard ${ }^{1,2}$, Mohammed Ater ${ }^{3}$ and John G. Hodgson ${ }^{1}$ \\ ${ }^{1}$ School of Archaeology, University of Oxford, 36 Beaumont Street, Oxford OX1 2PG, \\ United Kingdom \\ ${ }^{2}$ External Professor, Santa Fe Institute, 1399 Hyde Park Road, Santa Fe, New Mexico 87501, \\ USA \\ ${ }^{3}$ Department of Biology, Université Abdelmalek Essaâdi, B.P. 2062, 93030 Tétouan, \\ Morocco
}

\section{Introduction}

Arable weeds are plants that invade habitats created by people for the cultivation of other species. Though they are not the target of human cultivation, their growth in arable habitats means that they, like crops, are under human selection. Genetic studies of weedy crop relatives have documented traits (shattering/dehiscence, asynchronous flowering, seed dormancy etc.) that allow weeds to escape detection and eradication by farmers, and give them a competitive advantage over crops (Thurber et al. 2010, 2011; Qi et al. 2015). Selection of these traits in weedy crop relatives thus constitutes a (partial) reversal of the domestication syndrome (Hammer 1984), sometimes called ‘de-domestication’ (Ellstrand et al. 2010). But weeds can also adapt by taking on domestic traits (Hammer 1984); Harlan (1992: 66, 94) reports non-shattering populations of the weed Bromus secalinus and of weedy oats, for example. Moreover, genetic study of wild crop relatives and their domesticated counterparts has confirmed the importance of allele introgression from proximate wild populations (Song et al. 2014; Gutaker et al. 2017). The history of crops and weeds is thus deeply intertwined, the selection of traits in one shaping (directly and indirectly) the evolution of the other, in a particularly clear instance of mutual evolution through niche construction.

Another aspect of this complex relationship is summarized by Vavilov's distinction between 'primary' and 'secondary' domesticates, the latter thought to originate as arable weeds of the former (Vavilov 1992: 20). Hammer (1984) links secondary domesticates with the unconscious and gradual domestication of seed crops, in contrast to the conscious selection of traits in garden crops cultivated for their vegetative parts. Human selection in seed crop cultivation tends to operate at the level of the stand/field rather than the individual plant, thus encompassing both crops and weeds and bringing both under potential selection for domestic traits.

Widely cited examples of secondary domesticates are rye (Secale cereale L.) and oat (Avena sativa $\mathrm{L}$.). It is now known that both wild rye and oat were likely under cultivation by the $10^{\text {th }}$ millennium cal BC (Pre-Pottery Neolithic A) in the middle Euphrates and Jordan valley regions of south-west Asia, respectively (Weiss et al. 2006; Willcox 2008, 2009), alongside the wild progenitors of other cereals (barley, einkorn and emmer wheat). Unlike the latter, however, neither rye nor oat was part of the early domesticated package of crops that emerged in south-west Asia, though domestic (non-shattering) rye was reported from the established Neolithic site of Can Hasan III, central Anatolia (Hillman 1978). Sporadic archaeobotanical finds of rye in south-west Asia and Europe suggest that it mostly contaminated other cereal crops before emerging as a staple in temperate Europe from the Iron Age, expanding significantly during the early medieval period (Behre 1992; Zohary et al. 2012: 62-66). Oat possesses remarkable phenotypic plasticity as a weed, and can be a tolerated weedy supplement of other cereals (Harlan 1992: 66, 94). Archaeobotanical evidence suggests that it infested other cereals for millennia before emerging as a domesticated crop in central and western Europe, from the Roman period onward (Zohary et al. 2012: 69). Weedy origins have 
also been suggested for pulse crops such as common vetch (Vicia sativa L.) (Zohary et al. 2012: 95) and for other annual seed crops including opium poppy (Hammer 1984).

It is thus apparent that weeds are under genetic selection for invasiveness, and that their successful persistence in arable fields simultaneously brings them to the attention of farmers, who may choose to cultivate and (inadvertently) domesticate them. The weedy ecological niche thus both impinges negatively on crop growth, and offers an opportunity for human exploitation. As discussed further below, the practices of traditional subsistence farmers demonstrate a keen awareness of this paradox; though they may well regard weeds as harmful competitors, they are often knowledgeable of their potential uses, and open to opportunities to make use of the weeds they encounter in arable fields, in accordance with their needs.

In this paper we seek to disentangle crop husbandry and weed use further by distinguishing relevant weed ecological strategies and identifying different forms of human exploitation shaped by different agrosystems. We then use case studies to illustrate the potential of archaeobotanical remains of prehistoric weed flora associated with crops for reconstructing complex relationships among people, crops and weeds in the deep past. Our present-day and archaeological focus is western Asia, north Africa and Europe, and we have furthermore targeted annual cereal and pulse (seed) crops and their weeds.

Ethnobotanical and ecological perspectives on arable weeds

There is ample ethnobotanical support for the claim that arable weeds can form a valued part of the subsistence economy, including the study in northern Cameroon by Garine et al. (this volume). Palmer (1998) showed that hand-weeding in Jordan is associated with provision of fodder in small-scale herding, for example, while Ertuğ (2000: Table 1) has recorded the use of dozens of invasive species in central Anatolia, mainly as fodder and/or food.

Here we distinguish two broad categories of weed use: 1 . intentional collection of species with distinctively different growth habits and/or seasonality to the crop; and 2. collection (intentional or not) of species that closely mimic the crop in morphology and seasonality, making it difficult to avoid harvesting both. For simplicity we refer to the first group as 'opportunists' and the second group as 'mimics', though we recognize that there is a spectrum and thus overlap between these strategies. While both categories include noxious weeds that are inedible and even harmful to human or livestock consumers, both include species that can make a significant contribution to the household economy, as explored further below.

The 'opportunist' category is not only more readily distinguished from the crop, but may set seed well before and/or after crop harvest time, relying on a persistent bank of seeds in the soil from which to regenerate, and/or on vegetative regeneration from fragments of root/rhizome/stolon. Weeds of the 'mimic' category are more difficult to distinguish visually from the crop, often set seed around harvest time, hold their seeds at a similar height to the crop and possess seed morphology that imitates the size/shape of crop seed, enhancing their likelihood of being re-sown with the seed corn. These species may also have some seed dormancy, allowing them to persist in the soil to an extent, though mimics of large-seeded crops are less likely to form large persistent seed banks in the soil than small-seeded species (Thompson et al. 1993; Saatkamp et al. 2009, 2011). The 'mimic' category includes weedy crop relatives such as the wild millets discussed by Garine et al. (this volume).

In cereal and pulse fields, the distinction between opportunists and mimics parallels that between the broad phytosociological classes of Chenopodietea and Secalietea (Ellenberg et al. 1992: 72): root-/row-crop weeds that may grow opportunistically between row-sown or dibbled crops, versus mimicking weeds that thrive in dense crop stands. In a general sense the Chenopodietea and Secalietea characterize and help to discriminate between crop fields that are managed with relatively high and low labour intensity, respectively (Jones et al. 1999). 
To summarise thus far, 'opportunist' weeds include those that exploit fertile and highly disturbed habitats, while 'mimic' weeds follow the strategy of the crop as closely as possible. Cereals and pulses tend to be relatively competitive (tall/wide, fast growing), and to varying degrees demand fertile conditions, but require a certain period without mechanical soil disturbance in order to reach maturity. Thus crop mimics will tend to be less disturbancetolerant than opportunists, at least under highly fertile conditions. We would therefore expect 'opportunist' weeds to be more closely associated with labour-intensive maintenance of highly disturbed conditions (i.e. thoroughly tilled and hand-weeded), whereas crop mimics would be more prominent in less disturbed conditions (less thorough tillage and limited/no hand-weeding).

These broadly distinguished weed strategies create different opportunities for farmers. Opportunist weeds offer a potential source of human food and/or animal fodder over an extended time period, or at least for a period offset from that of the crop harvest, whereas mimics may usefully stretch/bulk out the main crop harvest itself (e.g Garine et al., this volume). Crop mimics, however, compete most directly with the crop, and pose an additional threat if they are noxious species that are difficult to separate from the crop and eradicate (e.g. Agrostemma githago - http://www.toxiplante.fr/monographies/nielle.html; Lolium temulentum infected with ergot fungus - Freeman 1904).

Hand-weeding in labour-intensive agrosystems in Morocco, including study sites in a recent weed ecological survey involving the present authors, offers a relevant case study (Bogaard et al. 2016a). Weeds in these systems tended to be viewed by farmers as a resource rather than merely as plants lowering crop yield, and were often used as fodder or food. We use functional ecological traits as a partial explanation of the evident value of weeds in this kind of system. Our observations suggest that hand-weeding is motivated not only by the removal of plants that compete with the crop, but also by the palatability of weed species that grow in highly fertile, disturbed and often shaded conditions.

Studies of herbivory and defensive characteristics (including chemical defense) in a range of plant species, from trees to ruderals, suggest that palatability is negatively correlated with growth rate and leaf life-span (Coley 1983; Southwood et al. 1986; Grime et al. 1996; Wright and Westoby 2002). Leaf traits have been shown to conform to a broad spectrum of variation irrespective of life form (Wright et al. 2004). We hypothesise that growth rate in arable weeds, as gauged through traits such as specific leaf area (SLA, the ratio of leaf area to leaf dry weight), is positively correlated with palatability, such that the weeds that thrive in very fertile and disturbed conditions also tend to be the most attractive for human and/or animal consumption.

Intensive hand-weeding of annual crops that form the basal layer of the oasis polyculture system is mentioned by various authors (e.g. Despois 1964; Baudoux et al. 2004; Ministry of Agriculture and Maritime Fishing 2009). As in the small Amtoudi oasis (Guelmim province, Morocco), where we conducted quadrat weed-survey of 16 cereal fields (six-row hulled barley, Hordeum vulgare L.) (Bogaard et al. 2016a), this is a task carried out mainly by women, who are therefore the experts in distinguishing useful and noxious species. We also surveyed a small number of cereal and pulse fields in the coastal part of Chefchaouen, northern Morocco, where small plots were also very intensively hand-weeded. A study of wild plant usage in the Rif region, including the prominent role played by arable weeds, is in progress (Bensbih and Ater 2017).

Despite clear climatic and biogeographical differences in the vegetation of northern and southern Morocco, the species composition of arable weed floras of intensively managed plots in both regions is very similar (Bogaard et al. 2016a: Fig. 2a). Labour-intensive management of these plots entailed manuring and (where needed) irrigation, as well as thorough tillage and hand-weeding (Bogaard et al. 2016a). Particularly characteristic of these 
plots were species such as Stellaria media (L.) Vill., Euphorbia peplus L. and Fumaria officinalis L., all with relatively thin leaves and high SLA values. A combination of thin leaves and high SLA values in annual plants predicts rapid growth through production of leaves with low construction costs, and an ability to make efficient use of phytosynthate in shaded conditions (Hodgson et al. 2011). In a UK study Stellaria media was shown to score particularly highly for herbivore palatability, coinciding with a short leaf life expectancy of around two weeks (Southwood et al. 1986). These are species of modest height and typically with smaller seeds than the crop; they fit within an opportunist rather than crop mimic category. The weed flora in these fields also contained other species with lower SLA values, including several relatively large-seeded grasses (Avena sterilis L., Bromus madritensis L., B. rubens L., Phalaris minor Retz.,) and other large-seeded species that tend to infest seed corn (e.g. Convolvulus arvensis L.), but classic crop mimics did not dominate the weed flora. Phalaris minor is considered noxious to livestock in Morocco (Lamnaouer and Abdennebi 1994).

Weeds in southern Moroccan oases are used particularly as animal fodder, in conjunction with small-scale and intensive livestock husbandry (e.g. house goats) (personal observations; cf. Palmer 1998). In the Rif region, by contrast, herding is large-scale and extensive, and an ongoing study by Bensbih and Ater (2017) reveals that arable weeds instead have a particular role as cooked greens in the human diet. The taxa recorded in the latter study include Papaver rhoeas L., a species of moderately high SLA also documented in intensively managed crop fields in coastal Chefchaouen (Bogaard et al. 2016a). Other species collected for human consumption in the Rif region and recorded as arable weeds in intensively managed fields include Malva spp. All of these taxa are collected (and sold) as 'bouquets' and also consumed as mixtures of species (Bensbih and Ater 2017) (Figure 1).

Traditional Moroccan agrosystems also harbour cases of wild crop relatives that are considered useful plants in their own right. Vicia sativa subspecies nigra (L.) Ehrh. is an example (Figure 2). This wild vetch grows in oasis barley fields as an opportunist, and displays distinctively 'wild' characteristics (asynchronous flowering, shattering) relative to cultivated forms of common vetch. It has been observed collected in bunches and drying on roofs as a fodder plant in the oasis of Imin-o-Iaouane, a relatively high altitude oasis (with almond orchards rather than date palms) on the southern slopes of the High Atlas, in the hinterland of Skoura (Ater, personal observations).

Elsewhere in Morocco, and in the wider Mediterranean, it is possible to observe more extensive traditional production systems with fewer labour inputs per unit area, including little to no hand-weeding (Bogaard et al. 2016a, b). These weed floras are variously characterized by less fertile, disturbed and shaded conditions, and by weed species of varying palatability for livestock and/or human consumers. In the Sault region and adjacent areas of Haute Provence, quadrat-weed survey of 60 fields has recently documented the weed flora associated with extensive organic cultivation of einkorn and other protected cereal landraces (Bogaard et al. 2016b). This weed flora is characterised by classic cereal mimics such as Agrostemma githago, the seeds of which are moderately toxic, and must be carefully removed to avoid spoiling flour and causing 'githagism' in consumers (http://www.toxiplante.fr/monographies/nielle.html). Other cereal mimics in this weed flora, such as Avena sterilis, have edible seeds and can also be used as fodder. A range of opportunistic weeds also occur in this weed flora. An ongoing collaborative project involving two of the present authors (Bogaard, Hodgson) and Yildiz Aumeeruddy-Thomas aims to clarify/communicate the potential uses (as human food, medicine or animal fodder) of the weed species in these organic cereal fields.

Finally, a recent study of the arable weed flora of décrue (flood recession) fields in the Guelmim province of southern Morocco offers a case study in weed use in the context of lowinput cultivation (Ater and colleagues, personal observations). Here, women practice the 
oasis-based tradition of weeding cereal fields for livestock, but must contend with a high proportion of non-palatable taxa (e.g. sclerophyllous and/or spiny/thorny) (Figure 3). Their strategy is to weed fields and then separate the weedy harvest into two groups: fodder (for their sheep, goats, cattle) and non-fodder. Spiny/thorny taxa are discarded on the margins of fields, and may be consumed by the camels of passing nomads. The farmers prefer handweeding to mechanized weed collection so that they can avoid incorporating spiny taxa in fodder.

Archaeobotanical evidence for the use of arable weeds in intensive and extensive agrosystems Three case studies serve to illustrate the potential of archaeobotanical remains of ancient arable weed flora for understanding complex ecological relationships among people, crops and weeds in the deep past, extending ethnobotanical insights from present-day studies. Here we briefly sketch the context and evidence available for agroecology and weed use at Neolithic Çatalhöyük, south-central Turkey (late $8^{\text {th }}$-late $7^{\text {th }}$ millennium BC), the Neolithic Linearbandkeramik (Linear Pottery Culture) complex of central and western Europe (later $6^{\text {th }}$ millennium BC) and the northern Mesopotamian Late Chalcolithic-Early Bronze Age ( $4^{\text {th }}-3^{\text {rd }}$ millennia BC). While the two Neolithic case studies shed light on intensive use of 'opportunist' weeds in labour-intensive agrosystems, the northern Mesopotamian case presents a contrasting scenario of intensive infestation of crop stores by (edible) weedy crop mimics that evidently made a significant contribution to the economy.

A notable constraint of the charred (carbonized) archaeobotanical evidence we consider here is that we are limited in our statements about past weed use to the collection/processing/storage of dense plant parts, especially seeds. Ethnobotanically, however, we know that farmers often make use of multiple plant parts, and some of the taxa considered below have edible vegetative parts as well as seeds.

Çatalhöyük

The archaeobotanical assemblage from the 1000-year Neolithic sequence at Çatalhöyük (c. 7100-6050 BC - Bayliss et al. 2015, Marciniak et al. 2015) attests to the collection and storage of a diverse range of wild species, including likely arable weeds (Fairbairn et al. 2007; Bogaard et al. 2013a, 2017). Potential weed taxa found in 'storage' concentrations include members of the Cruciferae/Brassicaceae family (especially Descurainia sophia (L.) Webb ex Prantl) and several grasses (Taeniatherum caput-medusae Nevski, Eremopyrum sp. (Ledeb.) Jaub. \& Spach). None of these species are close crop mimics. We focus here on the wild crucifer Descurainia sophia since it is attested very consistently throughout the sequence, and in great abundance in some 'storage' concentrations (e.g. 30 litres of cleaned seed in the storage bin of one burned building, Building 52) (Bogaard et al. 2013a, 2017). Wild mustard was likely valued for its oil-rich seeds; linseed/flax is very rare in the assemblage, and wild mustard offered a source of plant oil, alongside almonds and other nuts. A seed of this taxon was also recently observed embedded in a fragment of charred 'bread' (Gonzalez Carretero et al. 2017), adding support to the suggestion that is was a condiment alongside staple cereals and pulses (Bogaard et al. 2013a: 128). The tiny seeds of this taxon are much smaller than those of crops at Çatalhöyük; while is it thus not associated with relatively 'clean' (processed grain/seed) crops in archaeological storage contexts, its ubiquity and association in some deposits with crop processing by-products, together with its invasiveness in arable and ruderal habitats in the Konya plain today (Bogaard, personal observations), suggest that it was also an arable weed. Descurainia sophia thus appears to offer a clear example of an invasive weedy species that was valued in its own right as a source of human nutrition.

Similar examples of the collection of weedy members of the Cruciferae/Brassicaceae family as human food are also known elsewhere in western Asia (e.g. $10^{\text {th }}$ millennium BC Jerf el Ahmar - Willcox 2002) and Europe (Schlichtherle 1981). A particularly clear example including the same species (Descurainia sophia) is offered by a burned village-wide destruction layer at late Neolithic (early $4^{\text {th }}$ millennium BC) Hornstaad-Hörnle IA, on the 
southwestern shore of Lake Constance/Bodensee. Here charred clusters of the oil-rich seeds of $D$. sophia, other Cruciferae and some Labiatae/Lamiaceae (Galeopsis spp.) attest to deliberate/separate storage, while the dispersal of low levels of these same taxa through stored cereals shows that they were invasive in crop fields. As at Çatalhöyük, a case can be made that these species may have been the target of cultivation (Maier 2011), but their archaeological ubiquity and ecological invasiveness suggest that it would not be reasonable to assume that they were not (also) weeds of other crops.

The absence of domesticated cattle through much of the sequence at Çatalhöyük, and their low-level introduction in later phases, indicates that the agrosystem could only be based on manual cultivation. Detailed ecological work on the agroecology of Çatalhöyük is still underway, but the available evidence suggests that productive conditions were probably maintained to varying degrees by thorough tillage, hand-weeding and manuring (with sheep dung) and/or middening, a key constraint on the labour-intensity of management being the varying distance of fields across the surrounding alluvial plain from the densely nucleated settlement (including penning areas) (Bogaard et al. 2013a). It is apparent, therefore, that Çatalhöyük represents an established early farming community that practised relatively intensive arable land management and took advantage of the nutritional opportunities offered by certain 'opportunist' arable weed species. Occasional finds of the seeds of taxa that persist as arable weeds in cereal stubble after the harvest (Chenopodium L., Polygonum aviculare L.) in the matrix of charred sheep/goat dung pellets at Çatalhöyük suggests that certain weeds also played a role in the livestock diet (Bogaard et al. 2013a: 103).

\section{Linearbandkeramik (LBK; Linear Pottery Culture) complex}

It has long been appreciated by archaeobotanists working on assemblages from this widespread Neolithic horizon in lowland eastern-central-western Europe that for centuries LBK farmers made use of certain species that were almost certainly also arable weeds. The clearest case concerns fat hen/goosefoot (Chenopodium album L.), discussed extensively by various authors (Knörzer 1967, 1973, 1988, 1997; Bakels 1979, 1983/4, 1991; Willerding 1980; Lüning 2000: 92; Bogaard 2004, 2011; Kreuz 2007). The potential productivity and nutritional properties of $C$. album, a small-seeded relative of quinoa, have been discussed by Stokes and Rowley-Conwy (2002). As a potential cereal weed it is an opportunist species of relatively fertile/disturbed habitats, and its association with glume/hulled (einkorn and emmer) processing by-products on many LBK sites confirms that it was a regular constituent of cereal fields. The use of its seeds as a likely human food is directly suggested by the finding of 'pure' concentrations in pit fills on a range of sites, including the earliest LBK site of Niederhummel, Bavaria (Bogaard unpublished) as well as numerous later LBK settlements.

Detailed agroecological characterization of the LBK Neolithic through weed ecological analysis and more recently stable isotope analysis of associated crops (Bogaard 2004, 2011; Bogaard et al. 2013b) indicates that arable fields were managed to varying degrees with labour-intensive inputs, including likely hand-weeding and manuring/middening; the traditional 'slash and burn' model of Neolithic European farming simply does not fit the evidence. As at Çatalhöyük, and indeed some later Neolithic complexes in central Europe (lakeshore sites in the Alpine foreland - Jacomet et al. 2016), the LBK complex presents compelling evidence for a relatively small-scale intensive agrosystem that included use of species alongside crops that were likely arable weeds. Moreover, the key species appear to be opportunists that did not closely mimic the crop and could be readily separated/collected/stored in their own right.

\section{Northern Mesopotamia, Late Chalcolithic-Early Bronze Age}

The third case study presents a deliberate contrast to the others. The dry-farming belt of northern Mesopotamia was a cradle of early urbanism, parallel but agroecologically distinct from that which developed in the irrigated southern alluvium (Oates et al. 2007, Ur 2010). While early towns like Tell Zeidan on the Euphrates reached 12 ha by the $\mathrm{xx} 5^{\text {th }}$ millennium 
BC, by the later $4^{\text {th }}$ millennium (Late Chalcolithic 3) sites like Tell Brak exceeded 100 ha. This remarkable sequence of early urbanization, involving radically larger populations living in what appear to have been densely occupied cities, including temples and other institutional buildings, entailed equally radical agroecological change. A recent study by Styring et al. (2017) has shown that this agricultural process is best understood as extensification: the expansion of low-input management of cereals like two-row hulled barley and emmer wheat outwards from the urban cote, facilitated by animal traction, and inter alia accelerating landbased inequality (Bogaard et al. in press).

Large-scale storage of cereals is particularly well evidenced at EBA Tell Brak (TC complex - Emberling and MacDonald 2001, 2003; Hald and Charles 2008) and Tell Leilan (Acropolis storage complex - Weiss et al. 2002). Both of these complexes feature storage not only of domesticated cereals (e.g. hulled barley, emmer wheat) but also very abundant seeds of a cereal mimicking weed, Aegilops spp. This genus is closely related to wheats and barleys, falling within the same tribe (Triticeae) of the grass family. A. tauschii Coss. was the donor of the D chromosomes in hexaploid bread wheat (Triticum aestivum L.), which arose through alloploidization of A. tauschii with domesticated emmer (T. dicoccum Schrank) (Kilian et al. 2010). The large seeds of Aegilops closely mimic wheats and barleys, as do the plants in the field in seasonality and growth habit. Though we cannot be sure that Aegilops was an explicitly valued contribution to the economy, its abundance in stores and edibility indicate that, in effect, it was a significant component of the cereal harvest. The large scale of the TC complex at Brak, and apparently institutional nature of the Acropolis store at Leilan, suggest that it was above all extensive cultivation aimed at fulfilling institutional/taxation requirements, and forming an important basis of elite land-based power, that encouraged expansive of low-input cultivation favouring crop mimics such as Aegilops.

\section{Discussion and conclusions}

Ecologically the use/consumption (deliberate or not) of an edible crop mimic such as Aegilops can be contrasted with that of weedy species in the Neolithic cases reviewed above. While Aegilops broadened the subsistence base to an extent, it also competed directly with the desired crop, and would be subject to similar hazards of rainfall/weather since the ecological niches of crop and weed mimic would have been very similar. There is a hint from stable carbon isotope analysis of cereal grains and associated Aegilops grains in the Tell Leilan Acropolis store (Styring et al. 2017: Fig. 5a) that Aegilops completed photosynthesis even earlier than barley, suggesting that there were physiological differences that favoured earlier ripening of weed than crop.

In the cases of Çatalhöyük and the LBK complex, however, the 'opportunist' weeds exploited contrasted much more clearly with their associated crops, in ecology and nutritional value. The agrobiodiversity of these small-scale intensive systems, therefore, was significantly enhanced through exploitation of the weed flora, and more so than in the (inadvertent?) use of crop mimics in the extensive production systems of Early Bronze Age northern Mesopotamia. Moreover, had the crop mimic been a toxic species such as Agrostemma githago, the consequences for the value of the crop itself could be devastating. Potentially catastrophic effects of toxic crop mimics on crop stores are indeed known from Roman and medieval contexts, for example (e.g. Wiethold 1996).

In conclusion, it is clear that an appreciation of the potential uses of weeds - borne largely of necessity in subsistence farmer contexts - has been a valuable component of the economy for thousands of years. Consideration of weed ecology and the nature of the wider agrosystem upholds our hypothesis that labour-intensive subsistence systems tend to foster more valuable and diversified weed use than low-input extensive systems, such as those encouraged by the formation of dense urban centres with wide agricultural hinterlands and marked social differentiation. The resilience of long-lived Neolithic communities such as that at Neolithicearly Chalcolithic Çatalhöyük, which persisted in total from the late $8^{\text {th }}$ millennium to the mid 
$6^{\text {th }}$ millennium BC, relied not only on established staple crops but also systematic use of species that were invasive in arable habitats and presented new opportunities for diversification of the subsistence base (Bogaard et al. 2017). A simplistic 'domestic/wild' dichotomy fails to capture the subtlety and mechanics of crop/weed communities and their exploitation by humans.

Bibliography

Bakels C.C. 1979. Linearbandkeramische Früchte und Samen aus den Niederlanden. Archaeo-Physika 8, 1-10.

Bakels C.C. 1983/4. Pflanzenreste aus Niederbayern - Beobachtungen in rezenten Ausgrabungen. Bericht der Bayerischen Bodendenkmalpflege 24/25, 157-166.

Bakels C.C. 1991. Tracing crop processing in the Bandkeramik culture. In J. Renfrew (ed.) New Light on Early Farming, pp. 281-288. Edinburgh, Edinburgh University Press.

Bayliss, A., Brock F., Farid S., Hodder I., Southon J. \& Taylor R.E. 2015. Getting to the bottom of it all: a Bayesian approach to dating the start of Çatalhöyük Journal of World Prehistory 28, 1-26.

Baudoux L., Nieullet E., Druguet S., Jouve P., Seuge C., Ouabou R., Mouradi H. and Loussert R. 2004. Femmes et développement oasien, situation actuelle, initiatives et perspectives. Etudes de cas dans la région de Tata. Etudes thématiques en vue du développement des oasis de la région de Tata (Maroc) effectuées par des étudiants du CNEARC, Etude No. 2. Montpellier: CNERAC.

Behre K.-E. 1992. The history of rye cultivation in Europe. Vegetation History and Archaeobotany 1, 141-156.

Bensibh H. \& Ater M. 2017. Gathered food plants in northern Morocco. Unpublished poster.

Bogaard A. 2004. Neolithic Farming in Central Europe. London, Routledge.

Bogaard A. 2011. Plant Use and Crop Husbandry in an Early Neolithic Village: Vaihingen an der Enz, Baden-Württemberg. Frankfurter Archäologische Schriften. Bonn, Habelt-Verlag.

Bogaard, A., Charles M., Livarda A., Ergun M., Filipović D. \& Jones G. 2013a. The archaeobotany of mid-later Neolithic occupation levels at Çatalhöyük. In Hodder I. (ed.) Humans and Landscapes of Çatalhöyük: Reports from the 2000-2008 seasons, pp. 93-128. Los Angeles, Monographs of the Cotsen Institute of Archaeology, University of California at Los Angeles.

Bogaard A., Fraser R.A., Heaton T.H.E., Wallace M., Vaiglova P., Charles M., Jones G., Evershed R.P., Styring A.K., Andersen N.H., Arbogast R.-M., Bartosiewicz L., Gardeisen A., Kanstrup M., Maier U., Marinova E., Ninov L., Schäfer M. and Stephan E. 2013b. Crop manuring and intensive land management by Europe's first farmers. Proceedings of the National Academy of Sciences 110: 12589-12594.

Bogaard A., Filipović D., Fairbairn A., Green L., Stroud E., Fuller D. \& Charles M. 2017. Agricultural innovation and resilience in a long-lived early farming community: the 1500year sequence at Neolithic-early Chalcolithic Çatalhöyük, central Anatolia. Anatolian Studies.

Bogaard, A., A. Styring, M. Ater, Y. Hmimsa, L. Green, E. Stroud, J. Whitlam, C. Diffey, E. Nitsch, M. Charles, G. Jones, and J. Hodgson. 2016a. From traditional farming in Morocco to early urban agroecology in northern Mesopotamia: combining present-day arable weed surveys and crop isotope analysis to reconstruct past agrosystems in (semi-)arid regions. Environmental Archaeology, doi: $\underline{10.1080 / 14614103.2016 .1261217 . ~}$ 
Bogaard A., Styring A., Whitlam J., Fochesato M. \& Bowles S. in press. Farming, inequality and urbanization: a comparative analysis of late prehistoric northern Mesopotamia and southwest Germany. In Kohler T.A. \& Smith M.E. (ed.) Ten Thousand Years of Inequality: The Archaeology of Wealth Differences. Tucson, University of Arizona Press, Amerind Seminar Series.

Coley P.D. 1983. Herbivory and defensive characteristics of tree species in a lowland tropical forest. Ecological Monographs 53, 209-234.

Despois J. 1964. Les paysages agraires traditionnels du Maghreb et du Sahara septentrional. Annales de Géographie 73, 129-171.

Ellenberg H., Weber H.E., Düll R., Wirth V., Werner W. \& Paulissen D. 1992. Zeigerwerte von Pflanzen in Mitteleuropa. Scripta Geobotanica 18.

Ellstrand N.C., Heredia S.M., Leak-Garcia J.A., Heraty J.M., Burger J.C., Yao L., NohzadehMalakshah S. \& Ridley, C.E. 2010. Crops gone wild: evolution of weeds and invasives from domesticated ancestors. Evolutionary Applications 3, 494-504.

Emberling G. \& MacDonald H. 2001. Excavations at Tell Brak 2000: preliminary report. Iraq 63, 2154.

Emberling G. \& MacDonald H. 2003. Excavations at Tell Brak 2001-2002: preliminary report. Iraq $65,1-75$.

Ertuğ, F. 2000. An ethnobotanical study in central Anatolia (Turkey). Economic Botany 54, 155-182.

Fairbairn A.S., Martinoli D., Butler A. \& Hillman G. 2007. Wild plant seed storage at Neolithic Çatalhöyük East, Turkey. Vegetation History and Archaeobotany 16, 467-479.

Freeman E.M. 1904. The seed-fungus of Lolium temulentum, L., the Darnel. Philosophical Transactions of the Royal Society of London, B 196,1-27.

Gonzalez Carretero L., Wollstonecroft M., Fuller D.Q. 2017. A methodological approach to the study of archaeological cereal meals: a case study at Çatalhöyük East (Turkey). Vegetation History and Archaeobotany.

Grime J.P., Cornelissen J.H.C., Thompson K. \& Hodgson J.G. 1996. Evidence of a causal connection between anti-herbivore defence and the decomposition rate of leaves. Oikos 77, 489-494.

Gutaker R.M., Zaidem M., Fu Y.-B., Diederichsen A., Smith O., Ware R. \& Allaby, R.G. 2017. Adaptation to European latitudes through assimilation of wild diversity at the LuTFL1 locus altered architecture and promoted fiber production in flax. bioRxiv, doi: 10.1101/178772.

Hald M.M. \& Charles M. 2008. Storage of crops during the fourth and third millennia BC at the settlement mound of Tell Brak, north-east Syria. Vegetation History and Archaeobotany 17 (Suppl 1), 35-41.

Hammer K. 1984. Das Domestikationssyndrom. Kulturpflanze 32, 11-34.

Harlan J.R. 1992. Crops and Man. Second ed. Madison, Wisconsin: American Society of Agronomy.

Hillman G. 1978. On the origins of domestic rye - Secale cereale: the finds from Aceramic Can Hasan III in Turkey. Anatolian Studies 28, 157-174. 
Hodgson J.G., Montserrat-Martí G., Charles M., Jones G., Wilson P., Shipley B., Sharafi M., Cerabolini B.E.L., Cornelissen J.H.C., S.R. Band, Bogaard A., Castro-Díez P., Guerrero-Campo J., Palmer C., Pérez-Rontomé M.C., Carter G., Hynd A., Romo-Díez A., de Torres Espuny L. \& Royo Pla F. 2011. Is leaf dry matter content a better predictor of soil fertility than specific leaf area? Annals of Botany 108, 1337-1345.

Jacomet S., Ebersbach R., Akeret Ö., Antolín F., Baum T., Bogaard A., Brombacher C., Bleicher N.K., Heitz-Weniger A., Hüster-Plogmann H., Gross E., Kühn M., Rentzel P., Steiner B.L., Wick L. \& Schibler J.M. 2016. On-site data cast doubts on the hypothesis of shifting cultivation in the late Neolithic (c. 4300-2400 cal BC): Landscape management as an alternative paradigm. The Holocene 26, 1858-1874.

Jones G., Bogaard A., Halstead P., Charles M. \& Smith H. 1999. Identifying the intensity of crop husbandry practices on the basis of weed floras. Annual of the British School at Athens 94, 167-189.

Kilian B., Mammen K., Millet E., Sharma R., Graner A., Salamini F., Hammer K. \& Özkan H. 2010. Aegilops. In Kole C. (ed.) Wild Crop Relatives: Geonomic and Breeding Resources, Cereals, pp. 1-76. Heidelberg: Springer-Verlag.

Knörzer K.-H. 1967. Subfossile Pflanzenreste von bandkeramischen Fundstellen im Rheinland. Archaeo-Physika 2, 3-29.

Knörzer K.-H. 1973. Pflanzliche Großreste. Rheinische Ausgrabungen 13, 139-152.

Knörzer K.-H. 1988. Untersuchungen der Früchte und Samen. In U. Boelicke, D. von Brandt, J. Lüning, P. Stehli and A. Zimmerman (ed.) Der bandkeramische Siedlungsplatz Langweiler 8, Gemeinde Aldenhoven, Kreis Düren, pp. 813-852. Rheinische Ausgrabungen 28.

Knörzer K.-H. 1997. Botanische Untersuchung von 16 neolithischen Siedlungsplätzen im Bereich der Aldenhovener Platte, Kr. Düren und Aachen. In J. Lüning (ed.) Studien zur neolithischen Besiedlung der Aldenhovener Platte und ihrer Umgebung, pp. 647-684. Cologne, Rheinland-Verlag GmbH.

Kreuz A. 2007. Archaeobotanical perspectives on the beginning of agriculture north of the Alps. In S. Colledge and J. Conolly (ed.) The Origins and Spread of Domestic Plant in Southwest Asia and Europe. Walnut Creek, CA, Left Coast Press.

Lamnaouer D. \& Abdennebi E.H. 1994. Intoxications d'origine végétale chez les ovins du Maroc. In Boulanouar B. \& Paquay R. (ed.) L'élevage des moutons et ses systèmes de production au Maroc, pp. 335-352.

Lüning J. 2000. Steinzeitliche Bauern in Deutschland - die Landwirtschaft im Neolithikum. Universitätsforschungen zur prähistorischen Archäologie aus dem Seminar für Vor- und Frühgeschichte der Universität Frankfurt/M. 58.

Marciniak, A., Baranski M.Z., Bayliss A., Czerniak L., Goslar T., Southon J. \& Taylor R.E. 2015. Fragmenting times: interpreting a Bayesian chronology for the Late Neolithic occupation of Çatalhöyük East, Turkey. Antiquity 89, 154-176.

Maier, U. 2011. Archäobotanische Flächenuntersuchungen in der endneolithischen Siedlung Torwiesen II. Hemmenhofener Skripte 9, pp. check.

Ministry of Agriculture and Maritime Fishing. 2009. Elaboration de plans de développement des filières de production agricoles et des produits de terroir de la région de Guelmim Es-smara, Rapport de la 2ème phase: Ministry of Agriculture and Maritime Fishing, Regional Director of Agriculture Guelmim Es-smara. 
Oates J., McMahon A., Karsgaard P., Al Quntar S. \& Ur J. 2007. Early Mesopotamian urbanism: a new view from the north. Antiquity 81, 585-600.

Palmer, C. 1998. The role of fodder in the farming system: a case study from northern Jordan. Environmental Archaeology 1, 1-10.

Qi X., Liu Y., Vigueira C.C., Young N.D., Caicedo A.L., Jia L., Gealy D.R. \& Olsen, K.M. 2015. More than one way to evolve a weed: parallel evolution of US weedy rice through genetic mechanisms. Molecular Ecology 24, 3329-3344.

Saatkamp A., Affre L., Dutoit T. \& Poschlod P. 2011. Germination traits explain soil seed persistence across species: the case of Mediterranean annual plants in cereal fields. Annals of Botany 107, 415426.

Saatkamp A., Affre L., Dutoit T. \& Poschlod P. 2009. The seed bank longevity index revisited: limited reliability evident from a burial experiment and database analyses. Annals of Botany 104, 715724.

Schlichtherle H. 1981. Cruciferen als Nutzpflanzen in neolithischen Ufersiedlungen Südwestdeutschlands und der Schweiz. Zeitschrift für Archäologie 15, 113-124.

Song B.-K., Chuah T.-S., Tam S.M. \& Olsen K.M. 2014. Malaysian weedy rice shows its true stripes: wild Oryza and elite rice cultivars shape agricultural weed evolution in Southeast Asia. Molecular Ecology 23, 5003-5017.

Southwood T.R.E., Brown V.K. \& Reader P.M. 1986. Leaf palatability, life expectancy and herbivore range. Oecologia 70, 544-548.

Stokes P. \& Rowley-Conwy P. 2002. Iron Age cultigen? Experimental return rates for Fat Hen (Chenopodium album L.). Environmental Archaeology 7, 95-99.

Styring A.K., Charles M., Fantone F., Hald M.M., McMahon A., Meadow R.H., Nicholls G.K., Patel A.K., Pitre M.C., Smith A., Sołtysiak A., Stein G., Weber J.A., Weiss H. \& Bogaard A. 2017. Isotope evidence for agricultural extensification reveals how the world's first cities were fed. Nature Plants, DOI: 10.1038/nplants.2017.76

Thompson K., Band S.R. \& Hodgson J.G. 1993. Seed size and shape predict persistence in soil. Functional Ecology 7, 236-241.

Thurber C.S., Reagon M., Gross B.L., Olsen K.M., Jia Y. \& Caicedo, A.L. 2010. Molecular evolution of shattering loci in U.S. weedy rice. Molecular Ecology 19, 3271-3284.

Thurber C.S., Hepler P.K. \& Caicedo A.L. 2011. Timing is everything: early degradation of abcission layer is associated with increased seed shattering in U.S. weedy rice. BMC Plant Biology 11:14, 10.1186/1471-2229-11-14.

Ur, J. 2010. Cycles of civilization in northern Mesopotamia, 4400-2000 BC. Journal of Archaeological Research 18, 387-431.

Vavilov N.I. 1992. Origin and geography of cultivated plants. Cambridge University Press, Cambridge.

Weiss E., Kislev M.E. \& Hartmann A. 2006. Autonomous cultivation before domestication. Science 312, 1609-1610.

Weiss H., deLillis F., deMoulins D., Eidem J., Guilderson T., Kasten U., Larsen T., Mori L., Ristvet 
L., Rova E. \& Wetterstrom W. 2002. Revising the contours of history at Tell Leilan. Annales archéologiques arabes syriennes 45, 59-74.

Wiethold J. 1996. Von Dinkel, Einkorn und Kornrade: Archäobotanische Untersuchungen im Bereich der römischen Villenanlage von Borg, Kr. Merzig-Wadern. In 10 Jahre Ausgrabung Perl-Borg 19861996. Merzig, Landkreis Merzig-Wadern, Arbeitsverwaltung Merzig-Wadern.

Willcox G. 2002. Charred plant remains from a 10th millennium B.P. kitchen at Jerf el Ahmar (Syria). Vegetation History and Archaeobotany 11, 55-60.

Willcox G., Fornite S. and Herveux L. 2008. Early Holocene cultivation before domestication in northern Syria. Vegetation History and Archaeobotany 17, 313-325.

Willcox G., Buxo R. \& Herveux L. 2009. Late Pleistocene and early Holocene climate and the beginnings of cultivation in northern Syria. The Holocene 19, 151-158.

Willerding U. 1980. Zum Ackerbau der Bandkeramiker. Materialhefte zur Ur- und Frühgeschichte Niedersachsens 16, 421-456.

Wright I.J. and Westoby M. 2002. Leaves at low versus high rainfall: coordination of structure, lifespan and physiology. The New Phytologist 155, 403-416.

Wright, I.J., Reich, P.B., Westoby, M. et al. 2004. The worldwide leaf economics spectrum. Nature 428, 821-827.

Zohary, D., Hopf M. \& Weiss E. 2012. Domestication of Plants in the Old World. Fourth ed. Oxford University Press, Oxford.

\section{Figure captions}

Figure 1: Display of gathered plants including weedy Malva spp., market, Jeblia, Rif region, Morocco (photo: Mohammed Ater \& Hasnae Bensbih).

Figure 2: Vicia sativa subsp. nigra, growing as a weed of cereals in the oasis of Imin-oIaouane on the southern slopes of the High Atlas, Morocco (photo: Mohammed Ater).

Figure 3: Harvested décrue barley field, showing spiny weeds (Echinops spinosus), Guelmim province, Morocco (photo: Mohammed Ater \& Mohamed El Mahroussi). 